\title{
Erythropoiesis and Erythrophagocytosis in Bovine Haemal Nodes
}

\author{
Eritropoyesis y Eritrofagocitosis en Nodos Linfáticos Hemales de Bovino \\ "Cerutti, P. \& ** Guerrero, F.
}

CERUTTI, P. \& GUERRERO, F. Erythropoiesis and erythrophagocytosis in bovine haemal nodes. Int. J. Morphol., 26(3):557-562, 2008 .

SUMMARY: Whether bovine haemal nodes are involved in turnover of red blood cells has been a subject of some controversy. In this study, fluorescent and conventional optical microscopy of conventionally or immunohistochemically stained node sections, together with transmission electron microscopy, showed the presence of erythrocyte precursors and megakaryocytes, and evidence of active involvement in the destruction and replacement of old or degenerate red cells and the platelets.

KEY WORDS: Haemal nodes; Erithropoiesis; Erithrophagocytosis.

\section{INTRODUCTION}

The structure, fine structure and blood supply of haemal nodes are currently uncontroversial. In particular, current anatomical knowledge provides a basis for distinguishing between haemolymph nodes, which are endowed only with blood vessels (however, since this distinction is not made by all the authors cited in this paper, in what follows, we refer to other author's work using the term employed by those authors, and otherwise use the term "haemal" throughout). By contrast with their anatomy, the function of haemal nodes has not been fully elucidated: postulated functions include erythrophagocytosis, erythropoiesis, platelet formation and, most recently, immune functions (Turner, 1971; Cecarelli et al., 1986; Cerutti \& Guerrero, 2001).

Few authors have in fact suggested that erythropoiesis takes place in haemal nodes. Erencin (1948) reported that the haemolymph nodes of sheep and goats contain myeloid cells and erythroblast, and suggested that they act in the same way as bone marrow; and Salazar (1984) found bovine haemal lymph nodes to contain lymphoblast, myeloblats and erythroblast; but Folse et al. (1971) observed only megakaryocytes in bovine haemal nodes, and denied the possibility of erythropoiesis, myelopoiesis or erythrophagocytosis. Kitagawa et al. (1979) observed erythropoiesis in only 1 of 86 haemolymph nodes taken from goats in which circulating reticulocyte levels had risen to over $10 \%$ following the induction of haemolytic anaemia by injection of phenylhydrazine-HCL, and concluded that reticulocytes observed in these nodes had infiltrated from the circulation; the erythrocyte population of haemolymph nodes had a smaller proportion of reticulocytes than that of spleen.

As regard erythrophagocytosis, macrophages with abundant rough endoplasmic reticulum, free lysosomes, and numerous phagosomes containing erythrocyte débris have been observed in rat haemolymph nodes by Oláh \& Törö (1970) and in rat haemal nodes by Turner, who also found the sinuses of rat haemal nodes to contain macrophages with abundant haemosiderin in their cytoplasm. Lorvik et al. (1983), while ruling out the occurrence of erythropoiesis in bovine haemal nodes, considered that these structures have an erythrocatheretic function similar to that of the spleen (and that the presence of smooth muscle fibres implies that, like the spleen, they undergo rhythmic contractions).

Al-Bagdadi et al. (1986) observed plasmacytes with numerous cytoplasmic prolongations suggestive of motility and phagocytic activity to be randomly distributed in the medullary cords of the haemal lymph nodes of sheep. Their irregular perinuclear zones contained granular material of similar density to that of rough endoplasmic reticulum, and some showed morphological evidence of various phases of erythrophagocytosis, which had previously been observed only in pathological specimens. The phagocyted erythrocytes appeared to be smaller than usual. Most plasmacytes had Russel bodies in the cisternae of their rough endoplasmic

\footnotetext{
* Cátedra de Histología II y Embriología Especial. Facultad de Ciencias Veterinarias. Universidad Nacional de Rosario. Casilda. Argentina.

** Departamento de Anatomía y Producción Animal. Facultad de Veterinaria. Universidad de Santiago de Compostela. Lugo. España.
} 
reticulum, and some of the Russel bodies showed fuzzy borders and were separated from the endoplasmic reticulum by a halo of uniform width. The cytoplasm of many plasmacytes had become continuous with that of mast cells via cell junctions, thus allowing an exchange of immunospecific information reflected by increased numbers of histamine granules.

Finally, Ezeasor et al. (1989) observed erythrophagocytosis by macrophages, endothelial cells, reticular cells and occasional lymphocytes in transmission electron micrographs of caprine haemal nodes. Haemal node macrophages were similar to spleen macrophages in form and location, and exhibited similar lysosomal degradation of erythrocytes. These authors concluded that the architecture and cell composition of haemal nodes are appropriate for removal of erythrocytes from the circulation. In this situation, we are considered appropriated to make a histological study by using histological techniques applied by other authors, accompanied by more current detection's techniques. In this manner, we could corroborate the results obtained by others, in relation with the existence of erythropoiesis and erythrophagocytosis in bovine haemal nodes, or not. We are not considered necessary to achieve this objective to make any quantitative evaluation of the results. It may be a new aim's design and to lead to a new investigation work.

Here we report the findings of a study in which the possible occurrence of erythropoiesis and/or erythrocatheresis in bovine haemal nodes was investigated by transmission electron microscopy and by fluorescent and conventional optical microscopy of conventionally or immunohistochemically stained node sections.

\section{MATERIAL AND METHOD}

Seventy five haemal nodes were obtained from fifteen healthy Canadian Friesian cattle, including calves, yearlings and adults, following slaughter at the Oscar Mayer abattoir in Albacete, Spain. The animals were in excellent sanitary condition. From each animal, five haemal nodes were removed from the mesenteric and perirectal regions using a scalpel and tweezers. The proportions of material from the three age classes were maintained throughout subsequent processing.

Light microscopy. The nodes were cleaned of fat and sliced in half, and these half-nodes were fixed in $10 \%$ formaldehyde in $\mathrm{Na}_{2} \mathrm{HPO}_{4} / \mathrm{NaH}_{2} \mathrm{PO}_{4} \cdot \mathrm{H}_{2} \mathrm{O}$ buffer of $\mathrm{pH}=7.4$, embedded in paraffin wax, and cut in series of $2 \mu \mathrm{m}$ sections. The sections were warmed to $42^{\circ} \mathrm{C}$ in a water bath and mounted on clean poly-L-lysine-coated slides, and all except those destined for immunofluorescence microscopy were dewaxed with xylol and hydrated by passage through a series of increasingly dilute solutions of ethanol in water.

Dewaxed slides were stained with May-Grünwald Giemsa; subjected to Perl's Prussian blue reaction as modified by Gomori; or immunostained with streptavidinbiotin-labelled monoclonal antibodies against human glycophorin A (anti-GYPA) using diaminobenzidine as chromogen. Staining with streptavidin-biotin-labelled antiGYPA was performed using a Dako kit (ATOM K0680, Dako Corp., Carpentier, CA, USA); and stained sections were counterstained with Carazzi's haematoxylin; negative controls were treated with phosphate-buffered saline (PBS) or foetal bovine serum instead of anti-GYPA.

Paraffin sections were stained with phycoerythrin, CD 45 and CD 71 negative, labeled anti-GYPA. Negative controls were treated with PBS instead of anti-GYPA.

Slides were examined under a Nikon AF X_II microscope and photographed with a Nikon camera, except that immunofluorescent slides were examined under a Biorad MRC 1024 ES confocal microscope using a 100mW argon laser and a 580/32 filter.

Transmission electron microscopy. Haemal nodes were fixed by immersion for $24 \mathrm{~h}$ in $2.5 \%$ glutaraldehyde in $0.025 \mathrm{M}$ cacodylate buffer of $\mathrm{pH} 7$ containing sucrose. The fixed nodes were cut in pieces (respecting macroscopic structure), postfixed in $1 \%$ osmium tetróxide, rinsed in $0.025 \mathrm{M}$ cacodylate buffer, dehydrated in ethanol, and embedded (suitably oriented) in Epon 812. Half these blocks were cut either in $1 \mu \mathrm{m}$ sections that were stained with $1 \%$ toluidine blue, or in ultrathin $(70 \mathrm{~nm})$ sections that were collected on nickel grids and stained as per Reynolds (1963); ultrathin sections were examined using a transmission electron microscope.

\section{RESULTS}

Erythrophagocytosis. The occurrence of erythrophagocytosis in bovine haemal nodes was confirmed by the presence, in Prusian-blue-stained sections, of abundant haemosiderin in the haemal node sinuses and in the cytoplasm of some macrophages (Fig. 1A). TEM showed macrophages and polymorphonuclear cells performing erythrophagocytosis in the sinuses, and others with erythrocyte debris in their cytoplasm (Fig. 1B). 

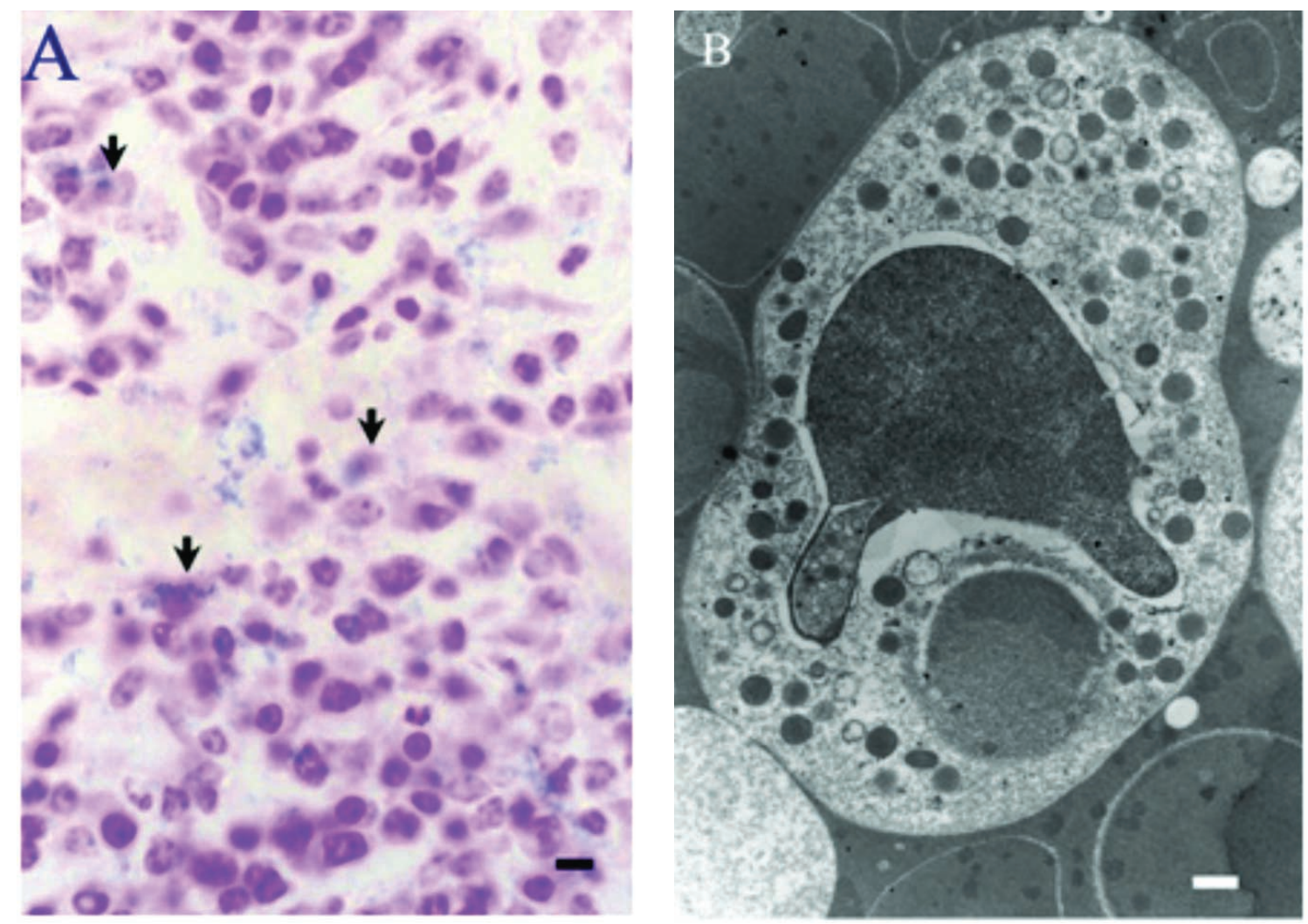

Fig. 1. A. Macrophages (arrowed) in a bovine haemal node (Prussian blue; bar= $100 \mu \mathrm{m})$. B. TE micrograph of an erythrocyte phagocyted by a macrophage in a bovine haemal node sinus (bar $=5 \mu \mathrm{m})$.

Erythropoiesis. In the collagenous capsule, Giemsa-stained sections showed elongated nuclei belonging to smooth muscle cells. Associated with the trabeculae of the sinuses there were 40-80 $\mu \mathrm{m}$ megakaryocytes with multilobed nuclei and granulated basophilic cytoplasm (Fig.2). The sinuses also contained both neutrophilic and eosinophilic granulocytes.

Small groups of red cells were observed in the subcapsular sinus, associated with perinodular lymphatic tissue, and also associated with the intrasinusoidal trabeculae; these cells were about $20 \mu \mathrm{m}$ in size, with a high nucleus/cytoplasm ratio, a vesicular nucleus, prominent nucleoli, and an intensely basophilic cytoplasmic ring, all of which identifies them as proerythroblats (rubriblats) (Fig.3).

In other regions of the nodes, in the lumen of the sinuses or in contact with their walls, there were 13-14 $\mu \mathrm{m}$ cells with small, dense, spherical nuclei and a mottled basophilic cytoplasm; these cells are tentatively identified as polychromatophilic erythroblast (rubricytes). The lumina of the sinuses also contained cells in the process of enucleation identified as orthochromatophilic erythroblast (metarubricytes).

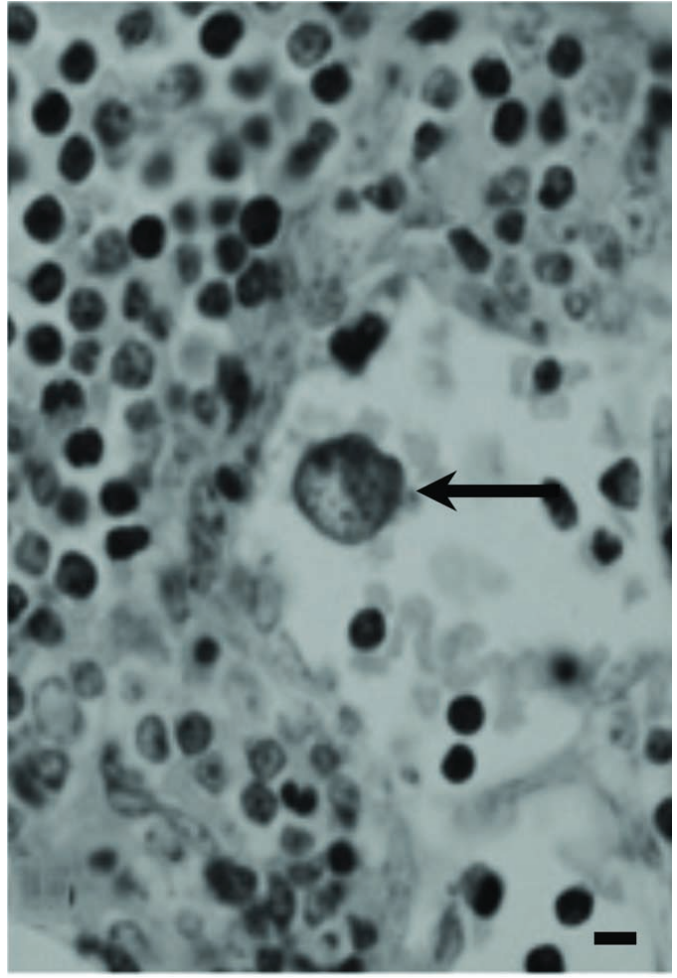

Fig. 2. Megakaryocyte (arrowed) in a bovine haemal node sinus (May-Grünwald Giemsa; bar $=20 \mu \mathrm{m}$ ). 

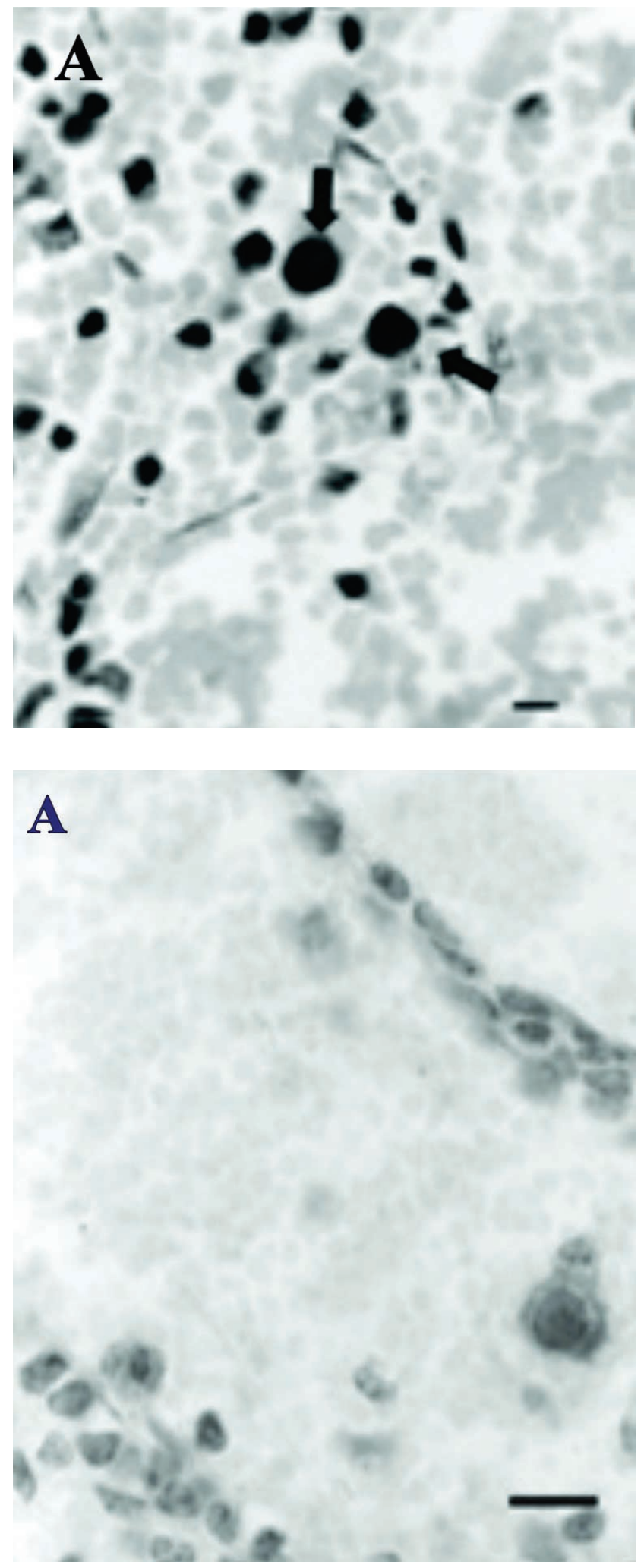

Fig. 4. Cells staining positive for glycophorin A in bovine haemal nodes. A: In the subcapsular sinus B: In a sinus trabecula. (bar= $40 \mu \mathrm{m})$.

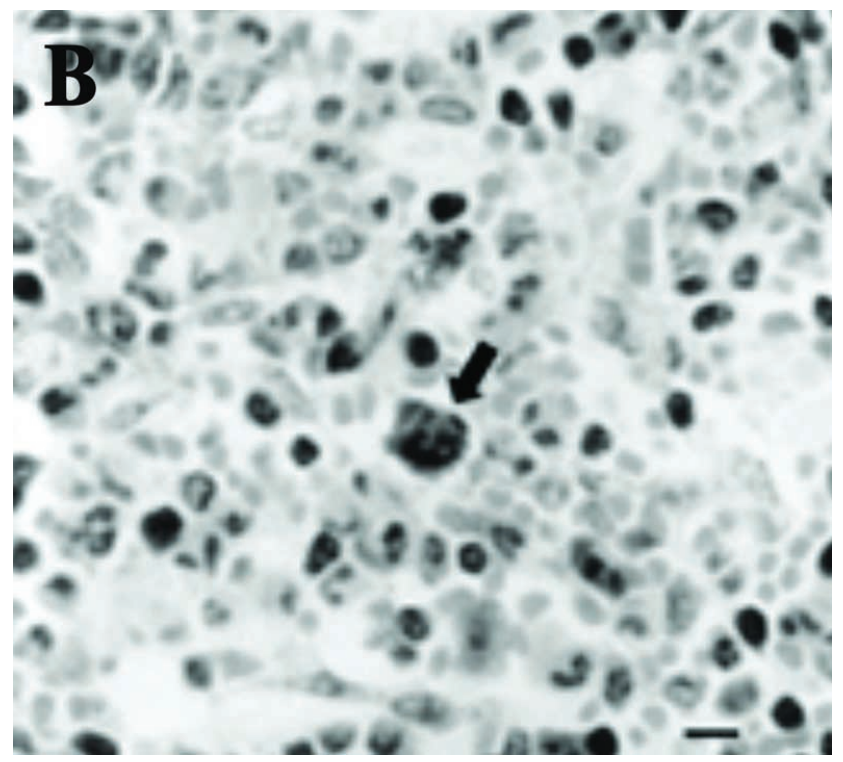

Fig. 3. Proerythroblats (rubriblats) associated with perinodular lymphatic tissue bordering the subcapsular sinus (A) and the

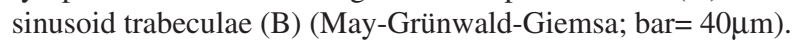

\section{B}

Cells positive for the erythroid-specific transmembrane protein glycophorin A were found in the haemal nodes examined by immunofluorescence microscopy and streptavidin-biotn-labelled anti-GYPA (Fig.4). These cells were found in the subcapsular sinus, the perinodular region and the trabeculae of the sinuses (Fig. 5B); they were less frequent in the lumina of the sinuses. These results correlate with those obtained by Giemsa staining and with streptavidin-biotin-labelled anti-GYPA (Figs. 5A and 5C). 

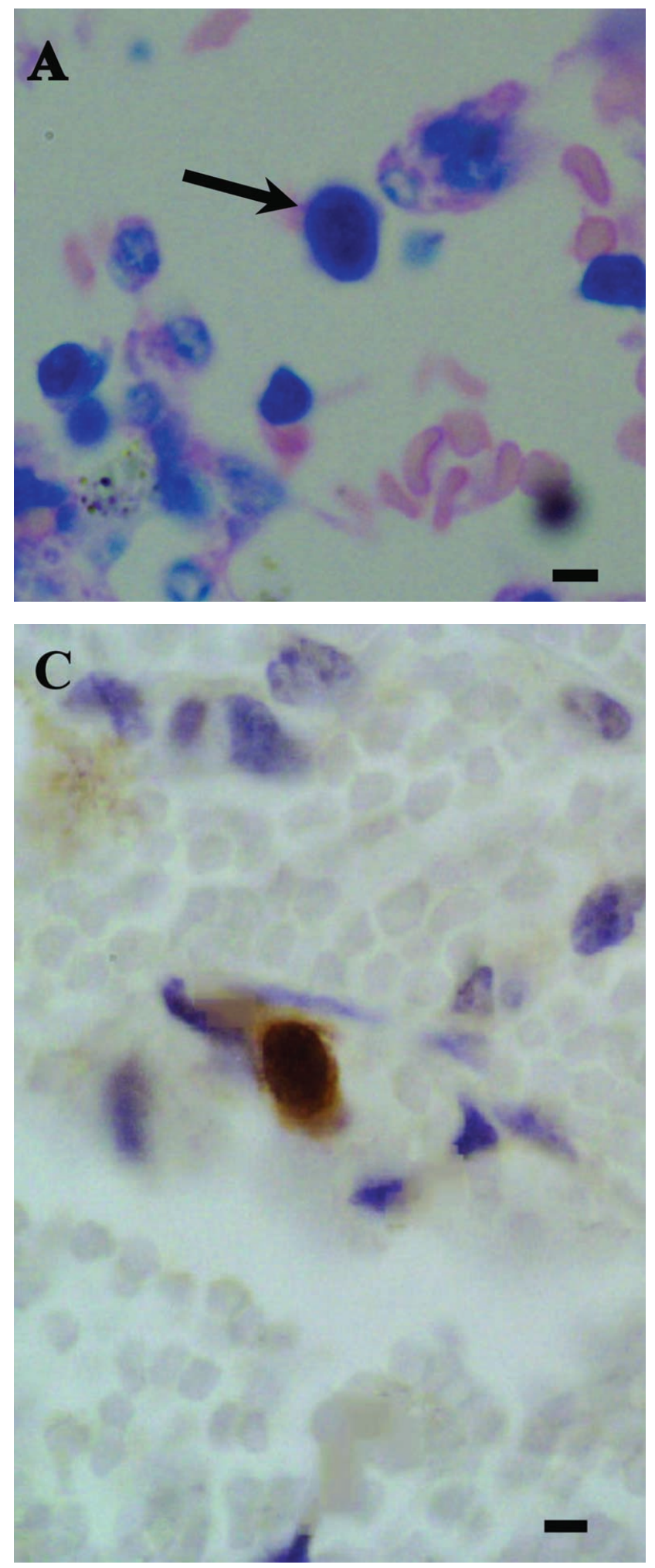

Fig.5. Red cells in sinuses of bovine haemal nodes. A: Polychromatophilic erythroblast (rubricytes) (May-GrünwaldGiemsa; bar $=40 \mu \mathrm{m})$. B: Cell staining positive for glycophorin A. Immunofluorescence microscopy. C: Cell staining with streptavidinbiotin-labelled anti-GYPA; (bar= 40 $\mu \mathrm{m})$.

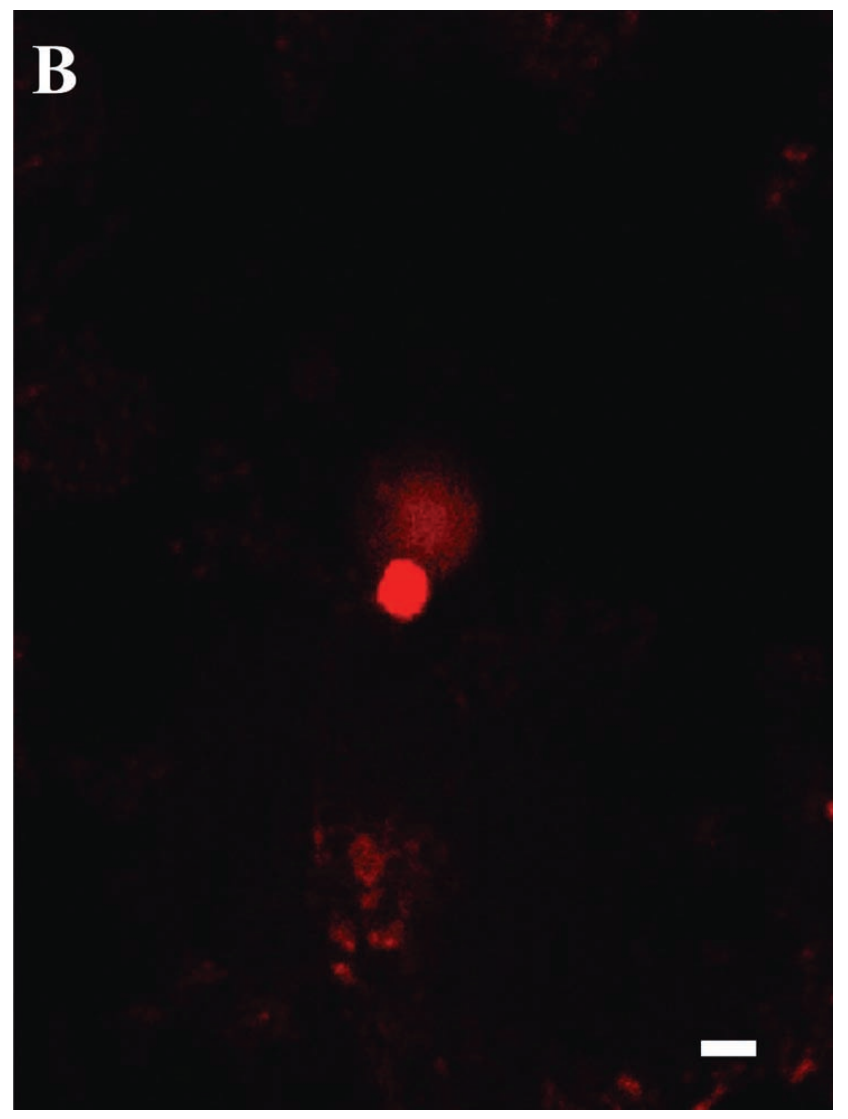

Taken together, the above findings indicate the following distribution of red cells in bovine haemal nodes. The perinodular region bordering the subcapsular sinus features small numbers of GYPA+ cells that on the basis of their size and large nucleus/cytoplasm ratio may be identified as probable proerythroblats or basophilic erythroblast. In the peritrabecular and medullary sinuses, and associated with the trabeculae, there are GYPA+ cells of smaller size (no larger than $14 \mu \mathrm{m}$ ), with smaller nuclei and limited cytoplasm, in the later stages of erythropoiesis (polychromatophilic and orthochromatophilic erythroblast). In short, these observations confirm the presence, in bovine haemal nodes, of cells in various stages of erythropoiesis.

\section{DISCUSSION}

Erythrophagocytosis is currently defined as the process by which an organism removes old or degenerate erythrocytes from the circulation. It is performed primarily by macrophages, mainly in the spleen but also in liver, lung, bone marrow and, in certain species, in haemal or haemolymph nodes (Ezeasor; Lorvik et al.; Oláh \& Törö; Turner). Although Folse et al., failed to detect erythrophagocytosis in bovine haemal nodes, they did ob- 
serve variation in the arrangement and colour of erythrocytes located in the sinuses, which indicates age differences among these cells.

Our findings in this study corroborate the performance of erythrophagocytosis in bovine haemal nodes. We observed large quantities of haemosiderin, the pigment produced by degradation of haemoglobin, in both the sinuses and the cytoplasm of some macrophages; and TEM images showed numerous macrophages and polymorphonuclear cells with erythrocyte debris in their cytoplasm or actually in the act of erythrophagocytosis.

In haemal nodes of goats, Ezeasor et al., reported observing erythrophagocytosis by endothelial cells, reticular cells, lymphocytes and eosinophils as well as by macrophages. Neither Ezeasor et al. nor we ourselves observed erythrophagocytosis by plasma cells, as Al-Bagdadi et al., did in haemal lymph nodes of healthy sheep.
The observation of erythroblast in haemolymph nodes was reported by Erencin and Salazar. In this study of bovine haemal nodes we observed red cells in several stages of erythropoiesis (proerythroblats and basophilic, polychromatophilic and ortochromatophilic erythroblast), and also megakaryocytes.

That bovine haemal nodes perform erythropoiesis was denied by Folse et al., and Lorvik et al., who failed to observe erythrocyte precursors, although Folse et al., did observe megakaryocytes; while Kitagawa et al., observed erythropoiesis in only 1 of 86 haemolymph nodes taken from goats in which erythropoiesis had been activated experimentally, and concluded that reticulocytes observed in these nodes had infiltrated from the circulation. The difference between Kitagawa et al. findings and our own may reflect structural and functional differences between haemal nodes and haemolymph nodes. The findings of this study corroborate the occurrence of both erythropoiesis and erythrophagocytosis in bovine haemal nodes.

CERUTTI, P. \& GUERRERO, F. Eritropoyesis y eritrofagocitosis en nodos linfáticos hemales de bovino. Int. J. Morphol., 26(3):557-562, 2008.

RESUMEN: Si nodos linfáticos hemales bovinos están involucrados en la cantidad de volumen de glóbulos rojos ha sido objeto de cierta controversia. En este estudio, secciones de nodos linfáticos teñidas convencionalmente o inmunohistoquímicamente fueron analizadas con microscopía óptica fluorescente y convencional, junto con microscopio electrónico de transmisión, los que revelaron la presencia de precursores eritrocíticos y megacariocitos, y la evidencia de participación activa en la destrucción y sustitución de glóbulos rojos viejos o degenerados y plaquetas.

PALABRAS CLAVE: Nodos linfáticos hemales; Eritropoyesis; Eritrofagocitosis.

\section{REFERENCES}

Al-Bagdadi, K. F.; Seger, C. L.; Titkemeyer, CH. W. \& Archbald, L. F. Ultrastructural Morphology of Plasma Cells in Normal Ovine Hemal Lymph Nodes. Anat. Histol. Embryol., 15 (4):344-54, 1986.

Carazzi, D. Eine neue Hämatoxylinlösung. Zeitschrift für wissenschaftliche Mikroskopie und für mikroskopiche Technik., 28:273, 1911.

Cecarelli, P.; Gargiulo, A. M.; Fagioli, O. \& Pedini, V. Cytochemical Identification of Lymphocytes and other Mononuclear Cells in Bovine Haemal Nodes. Comp. Immunol. Microbiol. Dis., 9(4):297-302, 1983.

Cerutti, P. \& Guerrero, F. Identification of Positive Cells to interleukin4 in Bovine Haemal Nodes. Anat. Histol. Embryol., 30:219-23, 2001.

Erencin, Z. Hemolymph Nodes in Small Ruminants. Am. J. Res., 9:291-5, 1948.

Ezeasor, D.; Singh, A. \& Sims, D. E. Erythrophagocytosis in the Caprine Hemal Nodes. Acta Anat. Basel, 134(4):341-5, 1989.

Folse, D.; Beathard, G. A.; Marshall, R. B.; Fish, J. C.; Sarlesw, H. E.; Remmers Jr. A. R. \& Ritzmann, S. E. Characterization of the
Bovine Hemal Node. J. Reticuloendothel. Soc., 10:461-81, 1971.

Kitagawa, H.; Kudo, N. \& Sugimura, M. Die Ultrastruktur der Blutlymphnoten bei Ziegen, insbesondere die Bewegung der Erythrozyten in den Knoten. Jap. J. Vet. Med. Sci., 27:3-4, 1979.

Lorvik, S.; Gargiulo, A. M.; Cecarelli, P. \& Fagioli, O. I Nodi Ematici del Bovino. Archivo veterinario italiano 34:3-4, 1983.

Oláh, I. \& Törö, I. Fine Structural Investigation of the Haemolymph Gland in Rat. Cytobiologie, 2(3):376-86, 1970.

Reynolds, E. S. The use of lead citrate at high $\mathrm{pH}$ as an electron opaque stain in electron microscopy. J. Cell Biol., 17:208, 1963.

Salazar, I. Consideraciones generales sobre los nódulos sanguíneos, Lymphonodi hemalis, en los rumiantes domésticos. Medicina Veterinaria, 1(10):473-80, 1984.

Turner, D. R. The Reticulo-Endethelial Components of the Haemal Node. J. Anat., 108(1):13-22, 1971.

Correspondence to:

Prfa. F. Guerrero

Histología

Facultad Veterinaria

Universidad Santiago Compostela

27002. Lugo - ESPAÑA

e-mail: castguer@usc.es

Received: 27-03-2008

Accepted: 12-05-2008 